\title{
Activity of Haliscosamine against Fusarium oxysporum f.sp. melonis: in vitro and in vivo analysis
}

\author{
Belakssem El Amraoui ${ }^{1,2^{*}}$, Jean François Biard ${ }^{3}$, Fatima Ez-Zohra kball $^{4}$, Majida El Wahidi ${ }^{2}$, Mostafa Kandil ${ }^{5}$, \\ Mohammed El Amraoui ${ }^{2}$ and Aziz Fassouane $e^{2,6}$
}

\begin{abstract}
Marine sponges are a potential source of new molecules with diverse biological activities. We have previously isolated a sphingosine derivative, (9Z)-2-amino-docos-9-ene-1,3,13,14-tetraol (Haliscosamine) from the Moroccan sea sponge Haliclona viscosa. The aim of this study was to test Haliscosamine in vitro and in vivo for its antifungal activity against Fusarium oxysporum f.sp. melonis causing fusarium wilt of melon.

Overall, in vitro test showed that haliscosamine has a similar effect as DESOGERME SP VEGETAUX ${ }^{\circledR}$. In addition, in vivo showed a significant effect against Fusarium oxysporum f.sp. melonis. Taking to gather, our results suggest that haliscosamine constitutes a potential candidate against Fusarium oxysporum f.sp. melonis and the possibility to use in phytopathology.
\end{abstract}

Keywords: Fusarium oxysporum; Porifera; Haliscosamine; Marine sponges; Haliclona

\section{Introduction}

Agriculture is an important economic sector in Morocco ; itemploys about $40 \%$ of the nation's workforce. The harvest of melon is popular in Morocco; it is found throughout the country. Moreover, Morocco is the $12^{\text {th }}$ largest exporter to export 55,000 tons of melon in 2009 (El Ouafi 2009). However, diseases that still cause problems in melon, are especially Fusarium followed by powdery mildew and bacterial blight (Messiaen et al. 1991). Fusarium wilt caused by Fusarium oxysporum f.sp. melonis (FOM), is a major disease affecting melon production in the province of El Jadida (Morocco) and causes important economic losses in this area. Thus, the suppression of this pathogen is considered urgent and a big challenge for this type of agriculture. Indeed, preventive treatment using chemical pesticides is the only way to fight these fungi. However, chemical pesticides sprayed into the air or discharged into the soil can be harmful to the environment and to humans. Biological antifungal may be an alternative. Furthermore, Marine sponges are a potential source

\footnotetext{
* Correspondence: elamraouibelkassem@yahoo.fr

${ }^{1}$ Faculté Polydisciplinaire de Taroudant, Université Ibn Zohr, Taroudant, Maroc

${ }^{2}$ Laboratoire Contrôle Qualité en Bio-Industrie et Molécules Bio-Actives, Faculté des Sciences, Université Chouaib Doukkali, BP 20, El Jadida 24000, Maroc

Full list of author information is available at the end of the article
}

of new biological compounds with diverse biological activities (Acosta and Rodriguez 1992; Baslow and Turlapaty 1969; Akiyama et al. 2009; Bao et al. 2007a; Bao et al. 2005; Bao et al. 2007b). In Morocco, few studies are carried out about Moroccan sponges with an important biological material for the isolation of new molecule (El Amraoui et al. 2014b; EL Amraoui et al. 2014a; El Amraoui et al. 2013; El Amraoui et al. 2010; El-Wahidi et al. 2011; El-Wahidi et al. 2013). Haliscosamine isolated from the Moroccan marine sponge Haliclona viscosa is a new derivative of sphingosine with an original molecular structure ((Z)-2-amino-docos-9- ene-1,3,13,14-tetraol) (El Amraoui et al. 2013). This compound is active against human pathogenic yeasts, Candida albicans, Candida tropicalis and Cryptococcus neoformans (El Amraoui et al. 2013).

To put it briefly, the aim of this study was to test the antifungal activity in vitro and in vivo of haliscosamine against Fusarium oxysporum f.sp. melonis.

\section{Results and discussion}

Antifungal in vitro test has shown that Haliscosamine is more active than DESOGERME SP against FOM with inhibition diameters of $21 \mathrm{~mm}$ and $19 \mathrm{~mm}$ respectively as illustrated in Figure 1. Haliscosamine showed fungicidal activity against FOM.

\section{空}




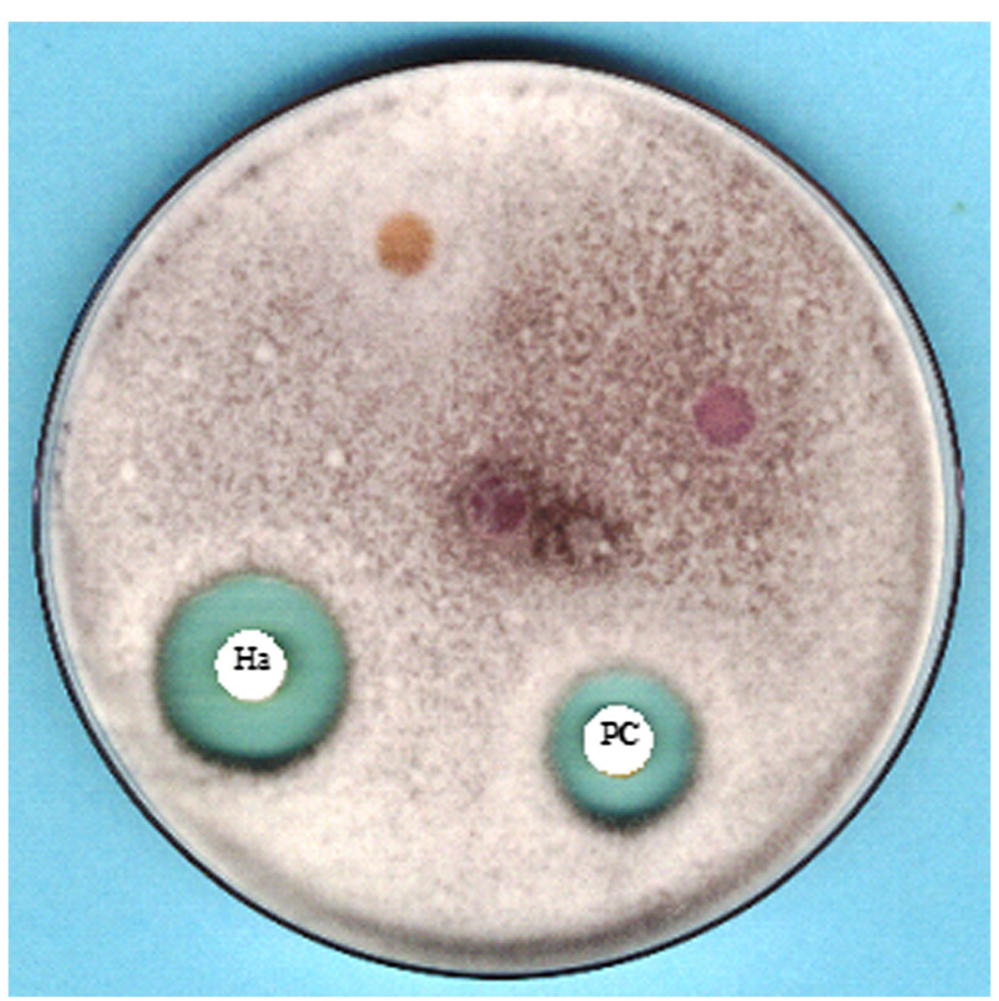

Figure 1 Example of in vitro antifungal activity of Haliscosamine (Ha) and DESOGERME SP (PC) against Fusarium oxysporum f.sp.melonis.

Interestingly, in vivo result showed that the average number of infected seedlings is significantly lower than the average number of infected seedlings in the positive control (Figure 2). Fusarium oxysporum f.sp. melonis had been suppressed by Haliscosamine treatment in infected plant with different concentrations (1\% and $2 \%$ ). This result indicates that the inhibition of Fusarium was a concentrationdependent manner of Haliscosamine (Figure 2).
Figure 3 shows the percentages of seedlings infected with the pathogen in each treatment and in the controls. No seedling $(0 \%)$ of the negative control uninfected (NCU) has presented infection while all seedlings $(100 \%)$ of the negative control infected (NCI) were infected.

The analysis of variance (ANOVA1) show highly significant $(\mathrm{P}<1 \%$ ) factor treatment (intergroup variation). Comparison of means by Duncan's test helped highlight

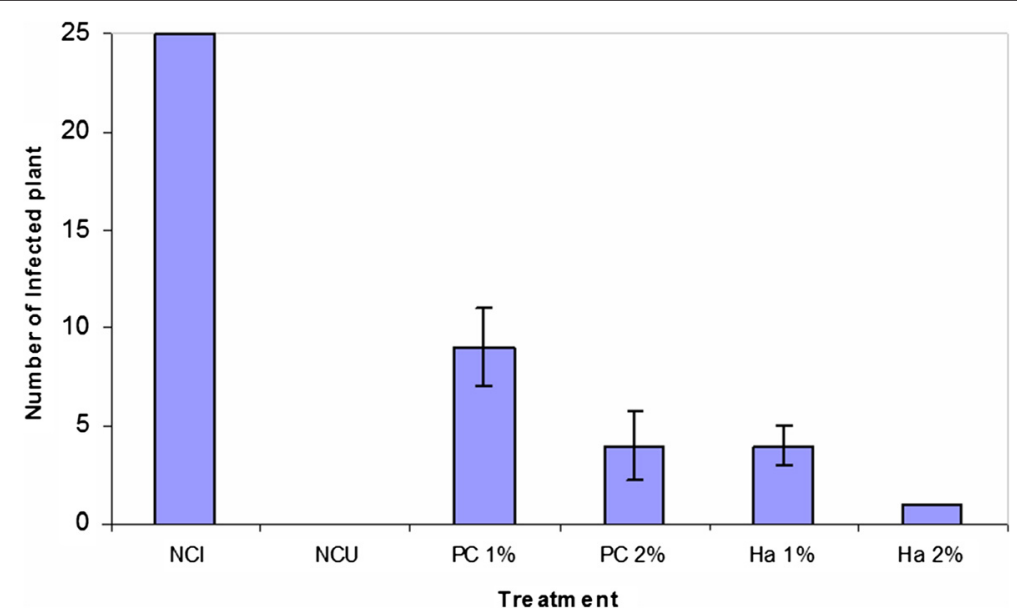

Figure 2 Average infected seedlings according to the in vivo treatment (NCl: Negative control infested, NCU: Negative control Uninfested, PC: positive control, Ha: Haliscosamine). 


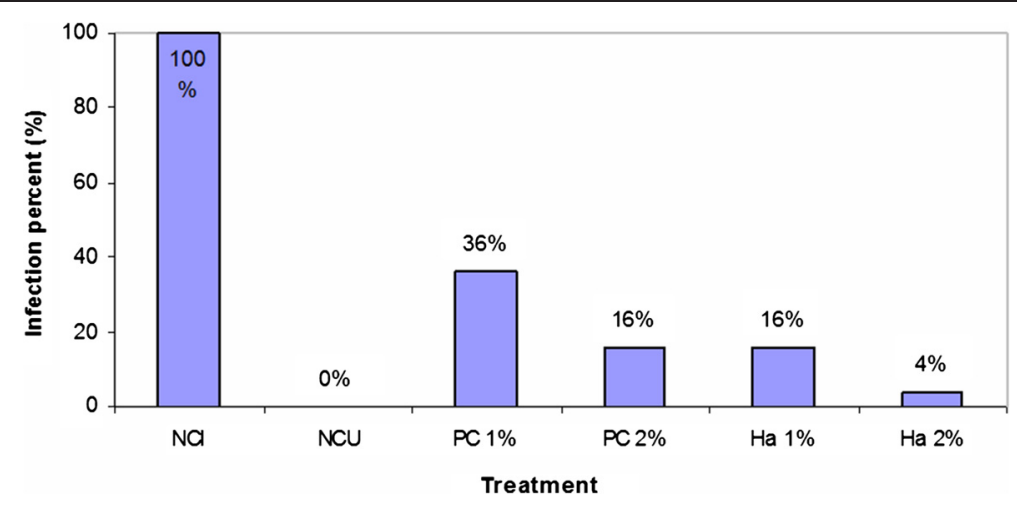

Figure 3 Percentages of seedlings infected with the pathogen in each treatment and in the controls (NCl: Negative control infested, NCU: Negative control Uninfested, PC: positive control, Ha: Haliscosamine).

homogeneous groups at the $5 \%$. Haliscosamine $1 \%$ has an effect similar to DESOGERME SP $2 \%$ on the inhibition of FOM. In comparison with the positive control, Haliscosamine has a significant inhibitory effect on the disease development.

The genus of Haliclona sponges are known for their high chemical various secondary metabolites with interesting biological activities (Faulkner 2002) including the antifungal (Barrett et al. 1996; Clark et al. 2001; Wattanadilok et al. 2007), antileishmanial (Dube et al. 2007), antioxidant (Regoli et al. 2004), cytotoxic (Erickson et al. 1997; Fusetani et al. 1989) and other activities (Hattori et al. 1998; Randazzo et al. 2001; Lakshmi et al. 2009; Roper et al. 2009).

Until now, the research that has been conducted on $H$. viscosa, led to the isolation of a number of alkaloids (Timm et al. 2010). Fuestani et al. (1989) have isolated two cytotoxic compounds, Haliclamine A and B from H. viscosa. Volk and Kock 2003 isolated viscosamine, two forms of viscosaline have recently been isolated (Schmidt et al. 2012). Two other alkaloids, haliclamine C and D, were isolated from $H$. viscosa (Volk et al. 2004). In a recently published work, Haliclona viscosa has shown significant antifungal activity against plant pathogenic fungi from Fusarium, Botrytis and Penicillium genus (El Amraoui et al. 2014b).

Haliscosamine isolated from Haliclona viscosa sponge, has a strong antifungal activity with a wide spectrum. It is active against human pathogenic yeasts (Candida albicans ATCC 10231, Candida tropicalis R2 CIP 1276.81 and Cryptococcus neoformans ATCC 11576) (El Amraoui et al. 2013) and against a very resistant phytopathogenic fungus (Penicilium digitatum) (EL Amraoui et al. 2014a).

Sponges, since a long time have been a major source of new biomolecules and they are still the inexhaustible source of new products with different biological activities; they can be used in various areas. Moroccan sponges are little studied, and yet they constitute a new biological material for researchers who are limited to medicinal plants and beach's invertebrates and algae.

\section{Conclusion}

Haliscosamine isolated from the Moroccan sponge, Haliclona viscosa showed in vitro fungicidal activity against redoubtable-phytopathogenic fungi. The in vivo studies of this product against Fusarium wilt showed promising results. Haliscosamine can be studied more effectively (open-field activity and toxicity) to see the possibility of its use as a biopesticide.

\section{Materials and methods \\ Phytopathogen strains}

The phytopathogen strain of the fungus Fusarium oxysporum f.sp. melonis, Fom 20474 CECT (Coleccion Espanola de Cultivos Tipo) was used in this study (Suárez-Estrella et al. 2007; Suárez-Estrella et al. 2004).

\section{Haliscosamine}

Haliscosamine is an antifungal isolated from the Moroccan marine sponge Haliclona viscosa. It is a new derivative of sphingosine with an original molecular structure $((Z)-$ 2-amino-docos-9- ene-1,3,13,14-tetraol) and it is active against human pathogenic yeasts, Candida albicans, Candida tropicalis and Cryptococcus neoformans. Haliscosamine used in this study, was isolated as described previously (El Amraoui et al. 2013).

\section{DESOGERME SP VEGETAUX ${ }^{\circledR}$}

DESOGERME SP VEGETAUX ${ }^{\oplus}$ (LAKORALE, Morocco), used in this study as a positive control, is an algaecide, fungicide and bactericide product used in Morocco both to remove algae, fungi and bacteria in irrigation systems and also to disinfect soil. It consists of $20 \mathrm{~g} / \mathrm{L}$ of polyhexamethyle bioguanidine hydrochlorique and $50 \mathrm{~g} / \mathrm{L}$ of $\mathrm{N}$-alkyl dimethyl benzyl ammonium chloride (EL Amraoui et al. 2014a). 


\section{In vitro antifungal activity}

This test uses Potato Dextrose Agar (PDA) as medium [Difco]. Conidial suspension was prepared from a 5-dold fungal culture (FOM culture was covered with $10 \mathrm{ml}$ of distilled water and then scraped with a sterile glass rod; spores were recovered after filtration on sterile wool cotton) and adjusted with Malassez's cellule in sterile water in order to obtain a final concentration of $10^{5}$ conidia $/ \mathrm{mL}$. Each disk $6 \mathrm{~mm}$ in diameter received $20 \mu \mathrm{g}$ of haliscosamine (20 $\mu \mathrm{L}$ of pur haliscosamine at $1 \mathrm{mg} / \mathrm{mL}$ in $\mathrm{CH}_{2} \mathrm{Cl}_{2}$ [Difco] were added to each cellulose disc) and then dried and placed on previously inoculated PDA medium. Plates were first kept at $4^{\circ} \mathrm{C}$ for at least two hours to allow the diffusion of chemicals, and then incubated at $28^{\circ} \mathrm{C}$. Inhibition was scored by the absence of any contact between the discs and fungi after $48 \mathrm{~h}$ of incubation then inhibition zones were measured. Standard disks of the DESOGERME SP VEGETAUX ${ }^{\circ}(20 \mu \mathrm{l} /$ disc $)$, served as the positive antifungal controls. All the assays were carried out in triplicate.

To determine whether the haliscosamine has fungistatic (temporary inhibition) or fungicide (permanent inhibition) effect on FOM, agar cylinder was cut out from inhibition zone and placed on the PDA medium and revival of their growth was observed. The fungicidal effect was where there was no growth after additional nine days of incubation at $25^{\circ} \mathrm{C}$; whereas, a fungistatic effect was where temporary inhibition of mycelial growth occurred (Askarne et al. 2012).

\section{In vivo antifungal activities of Haliscosamine and DESOGERME SP VEGETAUX ${ }^{\circledR}$ against Fusarium wilts of melon}

Haliscosamine was assayed in a greenhouse to determine if it possessed the ability to suppress Fusarium wilt of melon plants. In these tests, two DESOGERME SP VEGETAUX ${ }^{\circ}$ solutions, $1 \%$ and $2 \%$ were used as positive control.

Initially, seedlings of charentais melon (No resistance to Fusarium wilt) were planted in $20-\mathrm{cm}$-diameter pots containing $2.5 \mathrm{~L}$ of sterile substrate [Plantaflor PROFI TYP3]. The haliscosamine was dissolved in DMSO and solutions of $1 \%$ and $2 \%$ were prepared in the irrigation water. Then, the pots were irrigated for two days by each of these solutions. On the third day, a 7-d-old FOM culture grown in potato dextrose broth (PDB) was added to the pots containing plants. Pathogen inoculum which consisted of a mixture of conidia and chlamydospores, was added to the potting mix at a rate of 1000 propagules/g of substrate (Suárez-Estrella et al. 2007). Each treatment consisted of five replicate pots of five plants per pot. Disease was monitored for 6 weeks. Stem sections of all seedlings were destructively harvested and surface disinfected in $0.5 \%$ household bleach $(0.0026 \%$ sodium hypochlorite) and placed on PDA to confirm the presence of the pathogen. Results were shown as the total percentage of seedlings infected with the pathogen.

Two negative controls (without any prior treatment) were used:

- Negative control infested (NCI): All plants of NCI were infested with $F O M$ without any prior treatment.

- Negative control Uninfested (NCU): No plants of $\mathrm{CNU}$ has infected or treated.

\section{Statistical analysis}

One-way analysis of variance (ANOVA) was used to highlight the effect of treatment on the development of the plant pathogen. Averages of infected plants of different treatments were compared by Duncan test. P-value $<0.05$ was considered as a significant difference. Statistical analysis of data was performed using the SPSS software package 10.0 (SPSS Inc. USA).

\section{Competing interest}

All authors declare that they have no competing interest.

\section{Authors' contributions}

All authors read and approved the final manuscript.

\section{Acknowledgements}

We thank Dr. F. Suárez-Estrella from Alméria University, Spain who provide us with a Fusarium oxysporum f.sp. melonis strains and M. Mouchene, director of the agricultural department in LACORALE society (Morocco) who provide us with a DESOGERME SP VEGETAUX ${ }^{\circledR}$ and melon seeds.

\section{Author details}

${ }^{1}$ Faculté Polydisciplinaire de Taroudant, Université Ibn Zohr, Taroudant, Maroc. ${ }^{2}$ Laboratoire Contrôle Qualité en Bio-Industrie et Molécules Bio-Actives, Faculté des Sciences, Université Chouaib Doukkali, BP 20, El Jadida 24000, Maroc. ${ }^{3}$ Laboratoire MMS, Faculté de Pharmacie Université de Nantes, Nantes, France. ${ }^{4}$ Laboratoire de Physiologie végétale et phytopathologie, Faculté des Sciences, Université Chouaib Doukkali, BP 20, El Jadida 24000, Maroc. ${ }^{5}$ Laboratoire d'Anthropogénétiques et Biostatistiques, Faculté des Sciences, Université Chouaib Doukkali, BP 20, El Jadida 24000, Maroc. ${ }^{6}$ Ecole Nationale du Commerce et de Gestion ENCG de Settat, Settat, Maroc.

Received: 31 October 2014 Accepted: 5 January 2015

Published online: 13 January 2015

\section{References}

Acosta AL, Rodriguez AD (1992) 11-oxoaerothionin: a cytotoxic antitumor bromotyrosine-derived alkaloid from the Caribbean marine sponge Aplysina lacunosa. J Nat Prod 55(7):1007-1012

Akiyama T, Ueoka R, van Soest RW, Matsunaga S (2009) Ceratodictyols, 1-glyceryl ethers from the red alga-sponge association Ceratodictyon spongiosum/ Haliclona cymaeformis. J Nat Prod 72(8):1552-1554, doi:10.1021/np900355m

Askarne L, Talibi I, Boubaker H, Boudyach EH, Msanda F, Saadi B, Serghini MA, Ait Ben Aoumar A (2012) In vitro and in vivo antifungal activity of several Moroccan plants against Penicillium italicum, the causal agent of citrus blue mold. Crop Prot 40:53-58, doi:10.1016/j.cropro.2012.04.023

Bao B, Sun Q, Yao X, Hong J, Lee CO, Sim CJ, Im KS, Jung JH (2005) Cytotoxic bisindole alkaloids from a marine sponge Spongosorites sp. J Nat Prod 68 (5):711-715, doi:10.1021/np049577a

Bao B, Sun Q, Yao X, Hong J, Lee CO, Cho HY, Jung JH (2007a) Bisindole alkaloids of the topsentin and hamacanthin classes from a marine sponge Spongosorites sp. J Nat Prod 70(1):2-8, doi:10.1021/np060206z

Bao B, Zhang P, Lee Y, Hong J, Lee CO, Jung JH (2007b) Monoindole alkaloids from a marine sponge Spongosorites sp. Mar Drugs 5(2):31-39 
Barrett AG, Boys ML, Boehm TL (1996) Total Synthesis of (+)-Papuamine: An Antifungal Pentacyclic Alkaloid from a Marine Sponge, Haliclona sp. J Org Chem 61(2):685-699, doi:jo951413z

Baslow MH, Turlapaty P (1969) In vivo antitumor activity and other pharmacological properties of halitoxin obtained from the sponge Haliclona viridis. Proc West Pharmacol Soc 12:6-8

Clark RJ, Garson MJ, Hooper JN (2001) Antifungal alkyl amino alcohols from the tropical marine sponge Haliclona n. sp. J Nat Prod 64(12):1568-1571, doi:np010246x

Dube A, Singh N, Saxena A, Lakshmi V (2007) Antileishmanial potential of a marine sponge, Haliclona exigua (Kirkpatrick) against experimental visceral leishmaniasis. Parasitol Res 101(2):317-324

El Amraoui B, Biard JF, Uriz MJ, Rifai S, Fassouane A (2010) Antifungal and antibacterial activity of Porifera extracts from the Moroccan Atlantic coasts. J Mycol Med 20(1):70-74, doi:http://dx.doi.org/10.1016/j.mycmed.2009.11.001

El Amraoui B, Biard JF, Fassouane A (2013) Haliscosamine: a new antifungal sphingosine derivative from the Moroccan marine sponge Haliclona viscosa. Springerplus 2:252, doi:10.1186/2193-1801-2-252 363

EL Amraoui B, El Wahidi M, Fassouane A (2014a) Control of postharvest green mould of citrus by haliscosamine isolated from Haliclona viscosa sponge. EPPO Bulletin 44(1):73-77

El Amraoui B, El Wahidi M, Fassouane A (2014b) In vitro screening of antifungal activity of marine sponge extracts against five phytopathogenic fungi. SpringerPlus 3:629, doi:10.1186/2193-1801-3-629

El Ouafi H (2009) Melon: Le Maroc, $12^{\text {ème }}$ exportateur mondial. Agriculture du Maghreb. Accessed http://www.agriculturedumaghreb.com/agriculture/AdM/ archives/melon.pdf

El-Wahidi M, El-Amraoui B, Biard JF, Uriz MJ, Fassouane A, Bamhaoud T (2011) Variation saisonnière et géographique de l'activité antifongique des extraits de deux éponges marines récoltées sur le littoral atlantique d'El Jadida, Maroc. J Mycol Med 21:28-32

El-Wahidi M, El-Amraoui B, Fassouane A, Bamhaoud T (2013) Isolement bio-dirigé d'un antifongique à partir de Haliclona enamela récoltée du port de Jorf Lasfar, Maroc. J de Mycologie Médicale/J Med Mycol 23(2):91-96, doi:http://dx.doi.org/10.1016/j.mycmed.2013.04.006

Erickson KL, Beutler JA, Cardellina IJ, Boyd MR (1997) Salicylihalamides A and B, Novel Cytotoxic Macrolides from the Marine Sponge Haliclona sp. J Org Chem 62(23):8188-8192

Faulkner DJ (2002) Marine natural products. Nat Prod Rep 19(1):1-48

Fusetani N, Yasumuro K, Matsunaga S, Hirota H (1989) Haliclamines A and B, cytotoxic macrocyclic alkaloids from a sponge of the genus Haliclona. Tetrahedron Lett 30:6891-6894

Hattori T, Adachi K, Shizuri Y (1998) New ceramide from marine sponge Haliclona koremella and related compounds as antifouling substances against macroalgae. J Nat Prod 61(6):823-826

Lakshmi V, Srivastava S, Kumar Mishra S, Misra S, Verma M, Misra-Bhattacharya S (2009) In vitro and in vivo antifilarial potential of marine sponge, Haliclona exigua (Kirkpatrick), against human lymphatic filarial parasite Brugia malayi: antifilarial activity of $H$. exigua. Parasitol Res 105(5):1295-1301

Messiaen CM, Blancard D, Rouxel F, Lafon R (1991) Les maladies des plantes maraîchères, 3èmeth edn. INRA, Paris

Randazzo A, Bifulco G, Giannini C, Bucci M, Debitus C, Cirino G, Gomez-Paloma L (2001) Halipeptins A and B: two novel potent anti-inflammatory cyclic depsipeptides from the Vanuatu marine sponge Haliclona species. J Am Chem Soc 123(44):10870-10876

Regoli F, Nigro M, Chierici E, Cerrano C, Schiapparelli S, Totti C, Bavestrello G (2004) Variations of antioxidant efficiency and presence of endosymbiotic diatoms in the Antarctic porifera Haliclona dancoi. Mar Environ Res 58(2-5):637-640

Roper KE, Beamish H, Garson MJ, Skilleter GA, Degnan BM (2009) Convergent antifouling activities of structurally distinct bioactive compounds synthesized within two sympatric Haliclona demosponges. Mar Biotechnol (NY) 11(2):188-198

Schmidt G, Timm C, Grube A, Volk CA, Kock M (2012) Viscosalines B(1,2) and E $(1,2)$ : challenging new 3-alkyl pyridinium alkaloids from the marine sponge Haliclona viscosa. Chemistry 18(26):8180-8189, doi:10.1002/chem.201101362

Suárez-Estrella F, Vargas-Garcýa C, Lopeza MJ, Morenoa J (2004) Survival of Fusarium oxysporum f.sp. melonis on plant waste. Crop Prot 23:127-133

Suárez-Estrella F, Vargas-Garcýa C, Lopeza MJ, Capelb C, Morenoa J (2007) Antagonistic activity of bacteria and fungi from horticultural compost against Fusarium oxysporum f.sp. melonis. Crop Prot 26:46-53
Timm C, Mordhorst T, Kock M (2010) Synthesis of 3-alkyl pyridinium alkaloids from the arctic sponge Haliclona viscosa. Mar Drugs 8(3):483-497, doi:10.3390/md8030483

Volk CA, Kock M (2003) Viscosamine: the first naturally occurring trimeric 3-alkyl pyridinium alkaloid. Org Lett 5(20):3567-3569

Volk CA, Lippert H, Lichte E, Köck M (2004) Two New Haliclamines from the Arctic Sponge Haliclona viscosa. Eur J Org Chem 3154-3158. doi:10.1002/ ejoc.200400026

Wattanadilok R, Sawangwong P, Rodrigues C, Cidade H, Pinto M, Pinto E, Silva A, Kijjoa A (2007) Antifungal activity evaluation of the constituents of Haliclona baeri and Haliclona cymaeformis, collected from the Gulf of Thailand. Mar Drugs 5(2):40-51

\section{Submit your manuscript to a SpringerOpen ${ }^{\circ}$ journal and benefit from:}

- Convenient online submission

Rigorous peer review

- Immediate publication on acceptance

- Open access: articles freely available online

- High visibility within the field

- Retaining the copyright to your article

Submit your next manuscript at $>$ springeropen.com 